\title{
Bioavailability of total iron from meat, spinach (Spinacea oleracea L.) and meat-spinach mixtures by anaemic and non-anaemic rats*
}

\author{
BY D. ZHANG, D. G. HENDRICKS AND A. W. MAHONEY \\ Department of Nutrition and Food Sciences, Utah State University, Logan, \\ Utah 84322-8700, USA
}

(Received 20 April 1988 - Accepted 11 October 1988)

\begin{abstract}
1. Bioavailability of Fe from beef, spinach (Spinacea oleracea L.) and their mixtures was studied using anaemic and non-anaemic rats by haemoglobin regeneration efficiency (HRE) and apparent $\mathrm{Fe}$ absorption in two trials.

2. The initial haemoglobin levels of severely anaemic, mildly anaemic and non-anaemic rats were 63,88 and $113 \mathrm{~g} / \mathrm{l}$, respectively. The Fe level in diets was about $30 \mathrm{mg} / \mathrm{kg}$. All other nutrients equalled or exceeded the requirement of the growing rat.

3. The spinach Fe was well utilized by the rats with average HRE of $0.41,0.53$ and 0.36 , and apparent $\mathrm{Fe}$ absorptions averaging $0.48,0.59$ and 0.37 for the severely anaemic, mildly anaemic and non-anaemic animals respectively.

4. Beef Fe was efficiently used by rats as reported by others. Average HRE were $0.42,0.51$ and 0.44 , and average apparent $\mathrm{Fe}$ absorptions were $0.44,0.47$ and 0.46 for the severely anaemic, mildly anaemic and non-anaemic rats respectively.

5. When the percentage of meat Fe was increased from 0 to $25,50,75$ or 100 of the dietary Fe, HRE and apparent $\mathrm{Fe}$ absorption were not increased significantly. A meat enhancement effect on total Fe absorption, reported by others for non-haem-Fe, did not occur in the present experiment.

6. Negative correlation coefficients between initial haemoglobin and HRE $(r-0.79)$, and initial haemoglobin and apparent $\mathrm{Fe}$ absorption $(r-0.73)$ were seen with the rats fed on dietary $\mathrm{Fe}$ from $\mathrm{FeSO}_{4} \cdot 7 \mathrm{H}_{2} \mathrm{O}$. This was not seen with the rats fed on dietary Fe from beef or spinach.

7. The Fe absorption pattern for the different Fe sources is evidence for a third Fe pool, a pool made up of highly soluble inorganic $\mathrm{Fe}$ salt, in addition to haem-Fe and non-haem-Fe complex pools. $\mathrm{FeSO}_{4} \cdot 7 \mathrm{H}_{2} \mathrm{O}$ is not in the same gastrointestinal pool as non-haem-Fe complex such as spinach Fe. A suggested mechanism of absorption is discussed.
\end{abstract}

Fe deficiency is prevalent in the world. This is a result of low Fe absorption from food due to either low $\mathrm{Fe}$ intake or low bioavailability. Difference in absorption between haem-Fe in animal products and non-haem-Fe in plant foods has led to the two-pool hypothesis, which suggests the following routes of Fe absorption. Haem is efficiently absorbed intact into the intestinal mucosal cells where it is split to release the Fe (Weintraub et al. 1968; Turnbull, 1974). Non-haem-Fe must be solubilized and reduced before absorption and many factors affect this process (Layrisse et al. 1968, 1969; Cook \& Monsen, 1976; BjörnRasmussen et al. 1973; Gillooly et al. 1984; Wollenberg \& Rummell, 1987). The released haem-Fe and non-haem-Fe are transferred from the mucosal cells by the same mechanism. Non-haem-Fe absorption is measured by extrinsic labelling (Layrisse et al. 1968, 1969; Cook \& Monsen, 1976; Björn-Rasmussen et al. 1973). Meat enhances non-haem-Fe absorption (Martínez-Torres \& Layrisse, 1971; Björn-Rasmussen et al. 1973; BjörnRasmussen \& Hallberg, 1979; Layrisse et al. 1968, 1969; Cook \& Monsen, 1976). However, haem-Fe or total $\mathrm{Fe}$ absorptions were not measured in these studies; this information is necessary to determine the true impact of meat on Fe balance. The present study was concerned with the bioavailability of Fe from beef, spinach (Spinacea oleracea L.), or proportional mixtures of beef and spinach. Bioavailability in anaemic and non-anaemic rats was determined by haemoglobin regeneration efficiency (HRE) and apparent $\mathrm{Fe}$

* Paper no. 3606 of the Utah Agricultural Experiment Station. 
absorption, both of which are measures of total $\mathrm{Fe}$ utilization. The rat was used because its mechanism of haem-Fe absorption is similar to that of man (Turnbull, 1974; Thannoun et al. 1987).

MATERIALS AND METHODS

Experimental design

Diets with equal amounts of Fe were prepared by mixing lyophilized meat and lyophilized spinach in proportions to vary the added dietary $\mathrm{Fe}$ from $100 \%$ from meat $\mathrm{Fe}$ to $100 \%$ from spinach $\mathrm{Fe}$ (Table 1). A low-Fe basal diet to which about $20 \mathrm{mg} \mathrm{Fe}$ as $\mathrm{FeSO}_{4} \cdot 7 \mathrm{H}_{2} \mathrm{O} /$ $\mathrm{kg}$ were added served as a reference (Table 1). The effect of the Fe status of the rats on $\mathrm{Fe}$ utilization was tested in two trials. In trial 1, half the rats were severely anaemic and half were mildly anaemic. In trial 2 , half the rats were severely anaemic and half were kept nonanaemic.

Five rats in each group, a total of 120 rats, were used in the experiment. Body-weight gain, haemoglobin gain, haemoglobin-Fe gain and $\mathrm{Fe}$ intake were measured and used for calculating HRE. Faecal Fe and Fe intake were measured and used to calculate apparent $\mathrm{Fe}$ absorption. These methods of evaluation of $\mathrm{Fe}$ bioavailability were analysed and compared.

\section{Food and diet preparation}

Ground beef round and spinach were lyophilized for $48 \mathrm{~h}$ with the shelf temperature set at $40^{\circ}$. They were then ground in a blender fitted with stainless steel blades. The composition of these products is shown in Table 2.

The diets were formulated to provide $30 \mathrm{mg} \mathrm{Fe} / \mathrm{kg}$ diet (Table 1). Total protein, fat and fibre were balanced across diets to 180,100 and $50 \mathrm{~g} / \mathrm{kg}$ with casein, maize oil and cellulose respectively. Total calcium and phosphorus in the diets were held constant by adjusting the level of inorganic $\mathrm{Ca}$ and $\mathrm{P}$ added to the diets. Total sodium, potassium and $\beta$-carotene were also adjusted among diets according to literature values for these nutrients in meat and spinach (Agricultural Research Service, United States Department of Agriculture, 1963). The dietary ingredients were mixed in a stainless steel bowl and refrigerated in plastic bags until fed.

\section{Animals}

Male, weanling (50-60 g body-weight), Sprague-Dawley rats (Simonson Laboratories, Gilroy, CA) were individually housed in stainless steel cages with wire-mesh bottoms and fronts fitted with stainless steel funnels and glass apparatus for separating urine and faeces. Housing was in a temperature-controlled room $\left(22^{\circ}\right)$ with a $12 \mathrm{~h}$ light $-12 \mathrm{~h}$ dark cycle. Fresh demineralized water was given ad lib. in polypropylene bottles fitted with stainless steel lick-spouts and rubber stoppers. Fresh diet was given daily in glass feeders.

The rats were treated to be severely or mildly anaemic in trial 1, and severely anaemic and non-anaemic in trial 2, before the experimental diets were given. Severe Fe depletion was caused by giving the rats a low-Fe basal diet (about $10 \mathrm{mg} \mathrm{Fe} / \mathrm{kg}$ ) for $7 \mathrm{~d}$ and bleeding thirty drops of blood from the retro-ocular capillary bed of the rats (Timm, 1979) on days 1 and 4 . Heparinized glass capillary tubes were used to penetrate the orbital capillary bed to bleed the rats. The average haemoglobin concentration of these rats at the start of experiment was about 65 (SD 7) g/1 in trial 1 and 62 (SE 7) g/l in trial 2. Mild Fe depletion in trial 1 was caused by giving the rats a low-Fe basal diet for $7 \mathrm{~d}$ without bleeding, which lowered the haemoglobin level to 88 (SD 8) g/l. Non-anaemic rats in trial 2 were given an $\mathrm{FeSO}_{4} \cdot 7 \mathrm{H}_{2} \mathrm{O}$-supplemented diet to produce an average haemoglobin level of 113 (SD 7 ) $\mathrm{g} / \mathrm{l}$ at the end of $7 \mathrm{~d}$ of feeding. 
Table 1. Formulation of diets containing varying proportions of iron from meat and spinach (Spinacea oleracea $L$.) $(\mathrm{g} / \mathrm{kg})$

\begin{tabular}{|c|c|c|c|c|c|c|}
\hline \multirow[b]{2}{*}{$\begin{array}{r}\text { Meat Fe... } \\
\text { Ingredients Spinach Fe... }\end{array}$} & \multicolumn{6}{|c|}{ Proportion of $\mathrm{Fe}$ sources in diets } \\
\hline & $\begin{array}{r}1000 \\
0\end{array}$ & $\begin{array}{l}750 \\
250\end{array}$ & $\begin{array}{l}500 \\
500\end{array}$ & $\begin{array}{l}250 \\
750\end{array}$ & $\begin{array}{r}0 \\
1000\end{array}$ & $\underset{\text { diet }}{\mathrm{FeSO}_{4} \cdot 7 \mathrm{H}_{2} \mathrm{O}^{*}}$ \\
\hline Meat (lyophilized) & 187 & 140 & 94 & 47 & - & - \\
\hline Spinach (lyophilized) & - & $23 \cdot 5$ & 47 & $70 \cdot 5$ & 94 & - \\
\hline Casein & $38 \cdot 5$ & 70 & 101 & 134 & 166 & 198 \\
\hline Maize oil & $72 \cdot 3$ & $78 \cdot 5$ & $84 \cdot 6$ & $94 \cdot 7$ & 97 & 100 \\
\hline Cellulose & 50 & $48 \cdot 6$ & 47.2 & $45 \cdot 8$ & $44 \cdot 4$ & 50 \\
\hline $\mathrm{NaH}_{2} \mathrm{PO}_{4}$ & $25 \cdot 2$ & $25 \cdot 4$ & $25 \cdot 5$ & $25 \cdot 6$ & $25 \cdot 7$ & 26.9 \\
\hline $\mathrm{CaCO}_{3}$ & $16 \cdot 9$ & $16 \cdot 5$ & $16 \cdot 1$ & $15 \cdot 7$ & $15 \cdot 3$ & 17 \\
\hline Vitamin mixture & 20 & 20 & 20 & 20 & 20 & 20 \\
\hline Mineral mixture & $11 \cdot 6$ & $11 \cdot 6$ & $11 \cdot 6$ & $11 \cdot 6$ & 11.6 & 11.6 \\
\hline $\mathrm{NaCl}$ & 0.8 & $0 \cdot 6$ & 0.4 & 0.2 & - & 1.8 \\
\hline $\mathrm{KCl}$ & $4 \cdot 5$ & $3 \cdot 4$ & $2 \cdot 2$ & $1 \cdot 1$ & - & 9 \\
\hline$\beta$-Carotene $(\mathrm{mg} / \mathrm{kg})$ & 49 & 36.8 & 24.5 & $12 \cdot 3$ & - & 49 \\
\hline Glucose & $573 \cdot 2$ & 561.9 & $550 \cdot 4$ & $537 \cdot 8$ & $526 \cdot 0$ & $565 \cdot 7$ \\
\hline $\mathrm{Fe}(\mathrm{mg} / \mathrm{kg}) \S$ & $27 \cdot 4$ & $28 \cdot 0$ & $28 \cdot 6$ & 28.9 & 29.6 & $29 \cdot 5$ \\
\hline
\end{tabular}

* The ferrous sulphate reference diet was made by adding $0 \cdot 1000 \mathrm{~g} \mathrm{FeSO} \cdot 7 \mathrm{H}_{2} \mathrm{O}$ to $1 \mathrm{~kg}$ basal diet.

$\dagger$ The vitamin mixture contained $(\mathrm{g} / \mathrm{kg}): \alpha$-tocopherol $(10 \mathrm{mg} / \mathrm{g}) 5 \cdot 0$, L-ascorbic acid $45 \cdot 0$, choline chloride $75 \cdot 0$, D-calcium pantothenate $3 \cdot 0$, inositol $5 \cdot 0$, menadione $2 \cdot 25$, niacin $4 \cdot 5$, pyridoxine hydrochloride $1 \cdot 0$, riboflavin 1.0 , thiamin hydrochloride 1.0 , retinyl acetate $270 \mathrm{mg}$, calciferol $2.5 \mathrm{mg}$, biotin $20 \mathrm{mg}$, folic acid $90 \mathrm{mg}$, vitamin $B_{12} 1.35 \mathrm{mg}$, and glucose added to make to $1 \mathrm{~kg}$.

$\ddagger$ The mineral mixture contained $(\mathrm{g} / \mathrm{kg}): \mathrm{KCl} 296 \cdot 7, \mathrm{MgCO}_{3} 121, \mathrm{MnSO}_{4} 12 \cdot 7, \mathrm{CoCl}_{2} \cdot 6 \mathrm{H}_{2} \mathrm{O} 0 \cdot 7, \mathrm{ZnSO}_{4}$ $\cdot 7 \mathrm{H}_{2} \mathrm{O} 38, \mathrm{CuSO}_{4} \cdot 5 \mathrm{H}_{2} \mathrm{O} 1 \cdot 6, \mathrm{KI} 0 \cdot 8, \mathrm{NaMoO}_{4} \cdot 2 \mathrm{H}_{2} \mathrm{O} 0 \cdot 12$, glucose $528 \cdot 4$.

$\S$ Analysed value.

Table 2. Composition of lean ground beef and spinach (Spinacea oleracea $L.)^{*}$

\begin{tabular}{|c|c|c|c|c|c|c|}
\hline \multirow[b]{2}{*}{ Component } & \multicolumn{3}{|c|}{ Ground beef } & \multicolumn{3}{|c|}{ Spinach } \\
\hline & $\begin{array}{c}\text { Fresh } \\
\text { wt } \\
\text { basis }\end{array}$ & $\begin{array}{c}\text { Dry } \\
\text { wt } \\
\text { basis }\end{array}$ & $\begin{array}{l}\text { Nutrient } \\
\text { density } \\
(\mathrm{mg} / \mathrm{MJ})\end{array}$ & $\begin{array}{c}\text { Fresh } \\
\text { wt } \\
\text { basis }\end{array}$ & $\begin{array}{c}\text { Dry } \\
\text { wt } \\
\text { basis }\end{array}$ & $\begin{array}{c}\text { Nutrient } \\
\text { density } \\
(\mathrm{mg} / \mathrm{MJ})\end{array}$ \\
\hline Iron $(\mathrm{mg} / \mathrm{kg})$ & $29 \cdot 3$ & $107 \cdot 2$ & $5 \cdot 2$ & $19 \cdot 8$ & $213 \cdot 5$ & $18 \cdot 2$ \\
\hline Protein $(\mathrm{g} / \mathrm{kg})$ & 212 & 776 & - & 29 & 310 & - \\
\hline Fat $(\mathrm{g} / \mathrm{kg})$ & 40 & 148 & - & - & - & - \\
\hline Phosphorus (mg/kg) & 2000 & 7500 & 358 & 500 & 5200 & 454 \\
\hline Calcium $(\mathrm{mg} / \mathrm{kg})$ & 80 & 290 & 14 & 800 & 8340 & 741 \\
\hline
\end{tabular}

* Beef and spinach were freeze-dried before mixing with other diet ingredients. The fresh beef contained $727 \mathrm{~g}$ moisture $/ \mathrm{kg}$, and the fresh spinach contained $907 \mathrm{~g}$ moisture $/ \mathrm{kg}$.

On day 8 , all rats were weighed, haemoglobin concentration determined, and five rats were allotted to each of the six dietary treatment groups, balancing for haemoglobin concentration and body-weight. This was done by computer which first calculated the average haemoglobin concentrations of the severely anaemic, mildly anaemic or nonanaemic rats (thirty rats per group, two groups per trial). The groups were then subdivided by computer into six test groups allotting rats back and forth across the six diets, beginning by allotting animals with haemoglobin values equal to or above the mean and then allotting 
those with values below the mean. Body-weight was balanced by moving the rats with similar haemoglobin levels and different body-weights across the groups. The rats were given $9 \mathrm{~g}$ daily of their respective test diets for $10 \mathrm{~d}$.

\section{Evaluation methods}

$H R E$. All diet food given and that refused or spilled were weighed to determine total diet intake. Fresh diet was given to the rats every day. The initial and final body-weights and haemoglobin concentrations were determined to calculate HRE (Mahoney \& Hendricks, 1982). The formulas used were as follows:

$$
\begin{aligned}
& \text { haemoglobin-Fe }(\mathrm{mg})= \text { body-weight }(\mathrm{g}) \\
&\times \mathrm{ml} \text { blood } / \mathrm{g} \text { body-weight (assumed to be } 0.067 \mathrm{ml}) \\
& \times \mathrm{g} \text { haemoglobin } / \mathrm{ml} \text { blood } \\
&\times \mathrm{mg} \mathrm{Fe} / \mathrm{g} \text { haemoglobin (assumed to be } 3.35 \mathrm{mg}) . \\
& \mathrm{HRE}=\frac{\mathrm{mg} \text { haemoglobin-Fe (final) }-\mathrm{mg} \text { haemoglobin-Fe (initial) }}{\mathrm{mg} \mathrm{Fe} \text { consumed }}
\end{aligned}
$$

Apparent Fe balance. Apparent Fe absorption was calculated for each rat as follows:

$$
\text { apparent } \mathrm{Fe} \text { absorption }=\frac{\mathrm{Fe} \text { intake }(\mathrm{mg})-\text { faecal } \mathrm{Fe}(\mathrm{mg})}{\mathrm{Fe} \text { intake }(\mathrm{mg})} .
$$

The $\mathrm{Fe}$ in urine, perspiration and sloughed skin was considered negligible (Beutler, 1980). No urinary $\mathrm{Fe}$ was detected in the five rats sampled, so urine was not collected nor used in the formula.

\section{Chemical analysis}

The protein content of meat and spinach was measured by the Kjeldahl method with an automatic nitrogen analyser (Tecator Kjeltec Auto 1030 Analyser). The fat in the meat was measured by the Mojonnier method (Atherton \& Newlander, 1982). Samples for Fe measurement were wet ashed using sulphuric and nitric acids, and diluted to volume with demineralized water. $\mathrm{Fe}^{3+}$ in the sample was reduced to $\mathrm{Fe}^{2+}$ by hydroxylamine hydrochloride. $\alpha, \alpha$-Dipyridyl was used as a colour reagent to form a pink Fe complex. The absorbance was measured with a Beckman DB-GT grating spectrophotometer at $510 \mathrm{~nm}$ (Association of Official Analytical Chemists, 1980). Analysed values for National Bureau of Standards bovine liver (NBS 1577 ) and wheat flour (NBS 1567) reference samples were 177 (SD 7) $\mathrm{mg} \mathrm{Fe} / \mathrm{kg}$ (91\% of the certified value of 194 (SD 20) $\mathrm{mg} \mathrm{Fe} / \mathrm{kg}$ ) and 16 (sD 0.9) $\mathrm{mg} \mathrm{Fe} / \mathrm{kg}(90 \%$ of the certified value of 18.3 (SD 1.0) $\mathrm{mg} \mathrm{Fe} / \mathrm{kg}$ ) respectively. $\mathrm{P}$ was measured by colorimetry (Fiske \& Subbarow, 1925). Samples for Ca were ashed in a muffle furnace at $550^{\circ}$ for $48 \mathrm{~h}$ or until completely ashed. The ash was solubilized with $5 \mathrm{ml} 6 \mathrm{M}$ hydrochloric acid and diluted to volume with lanthanum oxide solution $(50 \mathrm{~g} / \mathrm{l})$ and deionized water (final sample solution containing $10 \mathrm{~g}$ lanthanum/1). Ca was measured with an atomic absorption spectrophotometer (model no. 457; Instrumentation Laboratories) using nitric oxide flame at $422 \cdot 7 \mathrm{~nm}$.

\section{Statistical analysis}

Results were analysed statistically by factorial analysis of variance (Dowdy \& Wearden, 1983). Two factors, Fe status of animals and dietary Fe source, were tested for their effect on Fe bioavailability. When $F$ was significant $(P<0.05)$, means were compared by least significant difference (LSD) values. The LSD test is suitable for multiple comparisons of 
mean differences (Carma \& Swanson, 1973). Correlation analysis was used to test if there was a linear relation between Fe status and $\mathrm{Fe}$ bioavailability indicators in varied dietary Fe sources. The significance of the correlation was tested by the one-tailed $t$ test (Dowdy \& Wearden, 1983).

\section{RESULTS}

Food composition

The protein, fat, total Fe, $\mathrm{P}$ and $\mathrm{Ca}$ contents of beef and spinach are summarized in Table 2. Spinach contained two-thirds as much $\mathrm{Fe}$ as beef on a fresh weight basis. However, on a dry weight or energy basis, spinach contained two to three times more Fe than beef. The beef and spinach used in the present study had similar amounts of P. However, beef contained little $\mathrm{Ca}$, about 0.02 of the $\mathrm{Ca}$ contained in spinach.

\section{Body-weight of rats}

The anaemic rats initially weighed less than the non-anaemic rats $(P<0.001)$, possibly due to the stress of blood lost and anaemia caused by the two phlebotomies during the 7-d depletion period. Rats in trial 1 fed on the low-Fe diet and not bled (mildly anaemic rats) initially weighed more than all other groups in both trials. The anaemic rats in trial 2 gained more weight than non-anaemic rats during the 10 -d repletion period $(P<0.001)$. Severely and mildly anaemic rats in trial 1 had similar body-weight gains. There were no significant differences in body-weight gains $(P>0.05)$ among groups of rats fed on the different diets. Differences in body-weight gain and Fe intake do not affect HRE (Mahoney et al. 1974; Mahoney \& Hendricks, 1976) if metabolizable Fe intake does not exceed Fe need.

\section{$H R E$}

HRE values and the values used to calculate them are listed in Table 3. Dietary Fe sources affected the haemoglobin gain $(P<0.001)$. After $10 \mathrm{~d}$ of Fe repletion, the haemoglobin concentration of rats receiving $\mathrm{FeSO}_{4} \cdot 7 \mathrm{H}_{2} \mathrm{O}$ increased the most. Rats fed on meat, meat-spinach or spinach diets gained similar amounts of haemoglobin, with the exception of the non-anaemic rats fed on the spinach diet which gained less haemoglobin. Anaemic rats gained more haemoglobin than non-anaemic rats $(P<0 \cdot 001)$. This was apparent when $\mathrm{FeSO}_{4} \cdot 7 \mathrm{H}_{2} \mathrm{O}$ and spinach $\mathrm{Fe}$ were the dietary $\mathrm{Fe}$ sources.

$\mathrm{Fe}$ status of the rats affected $(P<0.001)$ haemoglobin-Fe gain (Table 3$)$. There was a tendency for mildly anaemic rats (initial haemoglobin $88 \mathrm{~g} / \mathrm{l}$ ) to gain the most $\mathrm{Fe}$ as haemoglobin when dietary $\mathrm{Fe}$ was from spinach and meat. This was different from the rats fed on dietary $\mathrm{Fe}$ from $\mathrm{FeSO}_{4} \cdot 7 \mathrm{H}_{2} \mathrm{O}$, which showed an inverse relation between haemoglobin-Fe gain and initial $\mathrm{Fe}$ status. Haemoglobin-Fe gain was similar for the severely anaemic and non-anaemic rats when they were fed on diets with $\mathrm{Fe}$ from spinach and meat. The significant effect of dietary Fe source on haemoglobin-Fe gain $(P<0.001)$ was mainly the result of $\mathrm{FeSO}_{4} \cdot 7 \mathrm{H}_{2} \mathrm{O}$ which caused the greatest haemoglobin-Fe gain. However, rats fed on the meat, meat-spinach and spinach diets gained similar amounts of haemoglobin-Fe.

The Fe status of rats affected HRE $(P<0.001)$. When the dietary Fe source was spinach, the mildly anaemic rats had the highest average HRE. Rats fed on the diet with Fe from meat had similar average HRE, irrespective of Fe status. However, an inverse relation between initial $\mathrm{Fe}$ status and $\mathrm{HRE}$ was found in rats fed on the $\mathrm{FeSO}_{4} \cdot 7 \mathrm{H}_{2} \mathrm{O}$ diet. The significant effect of dietary Fe source on HRE $(P<0.001)$ was mainly the effect of $\mathrm{FeSO}_{4} \cdot 7 \mathrm{H}_{2} \mathrm{O}$ which caused higher $\mathrm{HRE}$ than all the other dietary groups. HRE values for anaemic rats fed on $\mathrm{FeSO}_{4} \cdot 7 \mathrm{H}_{2} \mathrm{O}$ were similar to those reported by Jansuittivechakul et al. 
Table 3. Body-weight, haemoglobin concentration, iron intake and haemoglobin regeneration efficiency $(H R E)$ for diets with varying amounts of Fe from meat or spinach (Spinacea oleracea $L$.) given to anaemic and non-anaemic rats

(Each value is the mean of five rats)

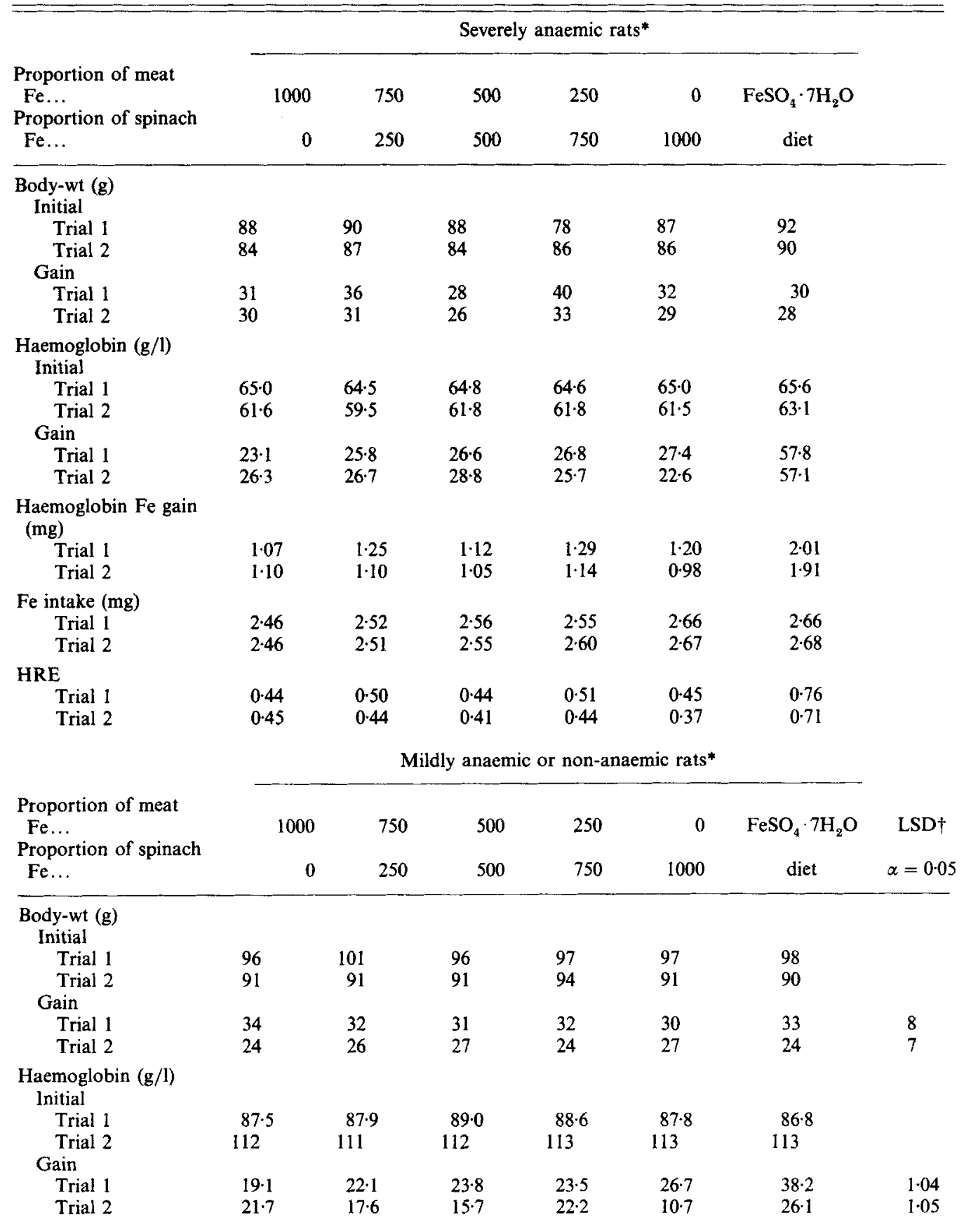


Table 3 continued.

\begin{tabular}{|c|c|c|c|c|c|c|c|}
\hline \multirow{3}{*}{$\begin{array}{l}\text { Proportion of meat } \\
\text { Fe... } \\
\text { Proportion of spinach } \\
\text { Fe... }\end{array}$} & \multicolumn{6}{|c|}{ Mildly anaemic or non-anaemic rats* } & \multirow{3}{*}{$\begin{array}{l}\text { LSD } \dagger \\
\alpha=0.05\end{array}$} \\
\hline & \multirow[t]{2}{*}{$\begin{array}{r}1000 \\
0\end{array}$} & \multirow[t]{2}{*}{$\begin{array}{l}750 \\
250\end{array}$} & \multirow[t]{2}{*}{$\begin{array}{l}500 \\
500\end{array}$} & \multirow[t]{2}{*}{$\begin{array}{l}250 \\
750\end{array}$} & \multirow[t]{2}{*}{$\begin{array}{r}0 \\
1000\end{array}$} & \multirow[t]{2}{*}{$\begin{array}{c}\mathrm{FeSO}_{4} \cdot 7 \mathrm{H}_{2} \mathrm{O} \\
\text { diet }\end{array}$} & \\
\hline & & & & & & & \\
\hline \multicolumn{8}{|l|}{$\begin{array}{l}\text { Haemoglobin } \mathrm{Fe} \text { gain } \\
(\mathrm{mg})\end{array}$} \\
\hline Trial 1 & $1 \cdot 25$ & $1 \cdot 28$ & $1 \cdot 30$ & $1 \cdot 32$ & $1 \cdot 38$ & $1 \cdot 75$ & 0.27 \\
\hline Trial 2 & $1 \cdot 16$ & $1 \cdot 11$ & $1 \cdot 12$ & $1 \cdot 19$ & 0.97 & $1 \cdot 29$ & $0-20$ \\
\hline \multicolumn{8}{|l|}{ Fe intake $(\mathrm{mg})$} \\
\hline Trial 1 & $2 \cdot 46$ & $2 \cdot 52$ & $2 \cdot 57$ & $2 \cdot 60$ & $2 \cdot 63$ & $2 \cdot 64$ & - \\
\hline Trial 2 & $2 \cdot 46$ & $2 \cdot 51$ & $2 \cdot 57$ & $2 \cdot 56$ & $2 \cdot 66$ & $2 \cdot 68$ & - \\
\hline \multicolumn{8}{|l|}{ HRE } \\
\hline Trial 1 & 0.51 & 0.51 & $0 \cdot 50$ & $0-51$ & 0.53 & 0.66 & $0 \cdot 10$ \\
\hline Trial 2 & 0.47 & 0.45 & 0.43 & 0.46 & 0.36 & 0.48 & 0.08 \\
\hline
\end{tabular}

* Mildly anaemic rats were used in trial 1 and non-anaemic rats were used in trial 2; for details see p. 335.

$\dagger$ LSD, least significant difference. Mean differences must be equal or exceed the LSD values to be statistically significant $(P<0.05)$.

Table 4. Correlation coefficients of initial haemoglobin $(\mathrm{Hb})$ v. $\mathrm{Hb}$ gain, $\mathrm{Hb}-\mathrm{Fe}$ gain, $\mathrm{Hb}$ regeneration efficiency ( $\mathrm{HRE}$ ) and apparent $\mathrm{Fe}$ absorption for rats fed on the $\mathrm{FeSO}_{4} \cdot 7 \mathrm{H}_{2} \mathrm{O}$, meat or spinach (Spinecea oleracea L.) diets*

\begin{tabular}{|c|c|c|c|}
\hline & $r \dagger$ & $t \ddagger$ & \\
\hline $\begin{array}{l}\text { Initial } \mathrm{Hb} v \text {. Hb } \\
\mathrm{FeSO}_{4} \cdot 7 \mathrm{H}_{2} \mathrm{O} \\
\text { Meat } \\
\text { Spinach }\end{array}$ & $\begin{array}{l}-0.85 \\
-0.21 \\
-0.47\end{array}$ & $\begin{array}{l}-6.69 \\
-0.92 \\
-2.25\end{array}$ & $\begin{array}{c}\text { S } \\
\text { NS } \\
\text { S }\end{array}$ \\
\hline $\begin{array}{l}\text { Initial } \mathrm{Hb} v \text {. } \mathrm{Hb} \text { - } \\
\mathrm{FeSO}_{4} \cdot 7 \mathrm{H}_{2} \mathrm{O} \\
\text { Meat } \\
\text { Spinach }\end{array}$ & $\begin{array}{r}-0.80 \\
0.24 \\
-0.09\end{array}$ & $\begin{array}{r}-5 \cdot 70 \\
1 \cdot 03 \\
-0 \cdot 38\end{array}$ & $\begin{array}{l}\text { S } \\
\text { NS } \\
\text { NS }\end{array}$ \\
\hline $\begin{array}{l}\text { Initial } \mathrm{Hb} v . \mathrm{HR} \\
\mathrm{FeSO}_{4} \cdot 7 \mathrm{H}_{2} \mathrm{O} \\
\text { Meat } \\
\text { Spinach }\end{array}$ & $\begin{array}{r}-0.79 \\
0.22 \\
0.07\end{array}$ & $\begin{array}{r}-5.48 \\
0.95 \\
0.29\end{array}$ & $\begin{array}{l}\text { S } \\
\text { NS } \\
\text { NS }\end{array}$ \\
\hline $\begin{array}{l}\text { Initial } \mathrm{Hb} \text { v. app } \\
\mathrm{FeSO}_{4} \cdot 7 \mathrm{H}_{2} \mathrm{O} \\
\text { Meat } \\
\text { Spinach }\end{array}$ & $\begin{array}{r}-0.73 \\
0.10 \\
-0.32\end{array}$ & $\begin{array}{r}-4 \cdot 51 \\
0.42 \\
-1 \cdot 40\end{array}$ & $\begin{array}{l}\text { S } \\
\text { NS } \\
\text { NS }\end{array}$ \\
\hline
\end{tabular}

* S, significant; NS, not significant. For details, see p. 338 .

$\dagger$ Each correlation coefficient was calculated from twenty pairs of experimental units.

$\ddagger t 0.05,18=1.73$. If $t>1.73$ or $t<-1.73$, the correlation coefficient was significant.

(1986). The HREs of rats fed on the diets formulated with meat, meat-spinach or spinach did not differ significantly. The only significant difference was that the HRE of nonanaemic rats in trial 2 fed on spinach $\mathrm{Fe}$ was lower than that of rats fed on meat or meat-spinach diets.

For rats fed on the $\mathrm{FeSO}_{4} \cdot 7 \mathrm{H}_{2} \mathrm{O}$ diet, there was an inverse relation between initial $\mathrm{Fe}$ 
Table 5. Liver, iron, faecal Fe and apparent Fe absorption for diets with varying amounts of meat and spinach (Spinacea oleracea $L$.) Fe fed to severely and mildly anaemic and nonanaemic rats

(Each value is the mean of five rats)

\begin{tabular}{|c|c|c|c|c|c|c|c|}
\hline \multirow{3}{*}{$\begin{array}{l}\text { Proportion of meat } \\
\text { Fe... } \\
\text { Proportion of spinach } \\
\text { Fe... }\end{array}$} & \multicolumn{6}{|c|}{ Severely anaemic rats } & \\
\hline & 1000 & 750 & 500 & 250 & 0 & & \\
\hline & 0 & 250 & 500 & 750 & 1000 & diet & \\
\hline \multicolumn{8}{|l|}{ Liver wt (g) } \\
\hline Trial 1 & 3.03 & $3 \cdot 14$ & $2 \cdot 87$ & $3 \cdot 30$ & 3.52 & 3.27 & \\
\hline Trial 2 & $2 \cdot 97$ & 3.09 & 3.03 & $3 \cdot 31$ & $3 \cdot 20$ & 3.07 & \\
\hline \multicolumn{8}{|l|}{ Liver $\mathrm{Fe}(\mu \mathrm{g} / \mathrm{g})$} \\
\hline Trial 1 & 26 & 23 & 24 & 29 & 25 & 35 & \\
\hline Trial 2 & 26 & 30 & 30 & 37 & 32 & 32 & \\
\hline \multicolumn{8}{|l|}{$\mathrm{Fe}$ in faeces $(\mathrm{mg})$} \\
\hline Trial 1 & $1 \cdot 12$ & $1 \cdot 10$ & $1 \cdot 11$ & 1.02 & 1.06 & 0.49 & \\
\hline Trial 2 & 0.94 & 0.91 & 0.94 & 0.97 & 1.02 & 0.43 & \\
\hline \multicolumn{8}{|l|}{$\begin{array}{l}\text { Apparent } \mathrm{Fe} \\
\text { absorption }\end{array}$} \\
\hline \multirow{3}{*}{$\begin{array}{l}\text { Trial } 1 \\
\text { Trial } 2\end{array}$} & 0.43 & 0.46 & 0.46 & 0.49 & 0.50 & 0.77 & \\
\hline & 0.45 & 0.48 & 0.48 & 0.46 & 0.46 & 0.79 & \\
\hline & \multicolumn{7}{|c|}{ Mildly anaemic or non-anaemic rats* } \\
\hline $\begin{array}{l}\text { Proportion of meat } \\
\text { Fe... }\end{array}$ & 1000 & 750 & 500 & 250 & 0 & $\mathrm{FeSO}_{4} \cdot 7 \mathrm{H}_{2} \mathrm{O}$ & LSD $†$ \\
\hline Proportion of spinach & & & & & & & \\
\hline $\mathrm{Fe} \ldots$ & 0 & 250 & 500 & 750 & 1000 & diet & $\alpha=0.05$ \\
\hline \multicolumn{8}{|l|}{ Liver wt (g) } \\
\hline Trial 1 & $3 \cdot 22$ & $3 \cdot 32$ & $3 \cdot 04$ & $3 \cdot 06$ & 4.03 & $3 \cdot 75$ & 0.42 \\
\hline Trial 2 & $3 \cdot 04$ & $3 \cdot 18$ & 3.05 & $3 \cdot 33$ & 3.25 & $3 \cdot 04$ & 0.39 \\
\hline \multicolumn{8}{|l|}{ Liver $\mathrm{Fe}(\mu \mathrm{g} / \mathrm{g})$} \\
\hline Trial 1 & 25 & 30 & 34 & 26 & 31 & 36 & 10 \\
\hline Trial 2 & 37 & 32 & 34 & 35 & 37 & 61 & 12 \\
\hline \multicolumn{8}{|l|}{$\mathrm{Fe}$ in faeces $(\mathrm{mg})$} \\
\hline Trial 1 & $1 \cdot 04$ & $1 \cdot 10$ & 1.01 & $1 \cdot 11$ & 0.85 & 0.56 & 0.18 \\
\hline Trial 2 & 0.93 & 1.03 & 0.97 & 0.95 & 1.16 & 0.88 & $0 \cdot 18$ \\
\hline \multicolumn{8}{|l|}{$\begin{array}{l}\text { Apparent } \mathrm{Fe} \\
\text { absorption }\end{array}$} \\
\hline Trial 1 & 0.47 & 0.46 & 0.51 & 0.47 & 0.59 & 0.73 & 0.09 \\
\hline Trial 2 & 0.46 & 0.41 & 0.47 & 0.46 & 0.37 & 0.54 & $0 \cdot 10$ \\
\hline
\end{tabular}

- Mildly anaemic rats in trial 1 and non-anaemic rats in trial 2; for details, see p. 339.

$\dagger$ LSD, least significant difference. Mean differences must be equal or exceed the LSD values to be statistically significant $(P<0 \cdot 05)$.

status and haemoglobin gain, haemoglobin-Fe gain or HRE, as shown in Table 4. The correlation coefficients between initial haemoglobin and these three variables were -0.85 , -0.80 and -0.79 , respectively (Table 4 ). However, the correlation coefficients between initial haemoglobin and these variables were not statistically significant for rats fed on diets containing $\mathrm{Fe}$ from meat or spinach, with the only exception of initial haemoglobin $v$. haemoglobin gain in rats fed on the spinach diet (Table 4). 
Table 6. Relative haemoglobin regeneration efficiency $(r H R E)$ and relative absorption of Fe ( $\mathrm{rAbs}$ ) from meat or spinach (Spinacea oleracea $\mathrm{L}$.) diets compared with the $\mathrm{FeSO}_{4}$ diet*

\begin{tabular}{|c|c|c|c|c|c|c|}
\hline $\begin{array}{l}\text { Proportion of meat } \mathrm{Fe} \ldots \\
\text { Proportion of spinach } \mathrm{Fe} . .\end{array}$ & $\begin{array}{r}1000 \\
0\end{array}$ & $\begin{array}{l}750 \\
250\end{array}$ & $\begin{array}{l}500 \\
500\end{array}$ & $\begin{array}{l}250 \\
750\end{array}$ & $\begin{array}{r}0 \\
1000\end{array}$ & $\underset{\text { diet }}{\mathrm{FeSO}_{4} \cdot 7 \mathrm{H}_{2} \mathrm{O}}$ \\
\hline \multicolumn{7}{|l|}{ Severely anaemic rats } \\
\hline \multicolumn{7}{|l|}{ Trial 1} \\
\hline rHRE & 58 & 66 & 58 & 67 & 59 & 100 \\
\hline rAbs & 56 & 60 & 60 & 64 & 65 & 100 \\
\hline \multicolumn{7}{|l|}{ Trial 2} \\
\hline rHRE & 63 & 62 & 58 & 62 & 52 & 100 \\
\hline $\mathrm{rAbs}$ & 57 & 61 & 61 & 58 & 58 & 100 \\
\hline \multicolumn{7}{|l|}{ Mildly anaemic rats } \\
\hline \multicolumn{7}{|l|}{ Trial 1} \\
\hline rHRE & 77 & 77 & 76 & 77 & 80 & 100 \\
\hline rAbs & 64 & 63 & 70 & 64 & 81 & 100 \\
\hline \multicolumn{7}{|l|}{ Non-anaemic rats } \\
\hline \multicolumn{7}{|l|}{ Trial 2} \\
\hline THRE & 98 & 94 & 90 & 96 & 75 & 100 \\
\hline $\mathrm{rAbs}$ & 85 & 76 & 87 & 85 & 69 & 100 \\
\hline
\end{tabular}

* For details, see p. 340 .

\section{Liver $\mathrm{Fe}$}

Liver Fe values are presented in Table 5. Dietary Fe source was the factor affecting liver weight $(P<0.001)$. The livers from rats fed on the spinach diet weighed more than those from rats fed on most of the other diets (LSD $0.22 \mathrm{~g}$ ). Liver Fe concentration was affected by both Fe status and dietary Fe source $(P<0.001)$. The concentration of liver Fe was highest in rats fed on the $\mathrm{FeSO}_{4} \cdot 7 \mathrm{H}_{2} \mathrm{O}$ diet, and was particularly high in the non-anaemic rats (trial 2). There were no differences in the concentration of liver $\mathrm{Fe}$ among the groups of rats fed on meat, meat-spinach or spinach. Non-anaemic rats had higher liver Fe concentrations (LSD $4.3 \mu \mathrm{g} / \mathrm{g}$ ) at the end of the experiment than severely and mildly anaemic rats. The concentration was especially higher in rats fed on the $\mathrm{FeSO}_{4} \cdot 7 \mathrm{H}_{2} \mathrm{O}$ diet. However, there was no significant difference in liver Fe concentration between severely and mildly anaemic rats in any other diet groups.

\section{Apparent Fe absorption}

Both $\mathrm{Fe}$ status and dietary $\mathrm{Fe}$ source affected faecal $\mathrm{Fe}$ excretion and apparent $\mathrm{Fe}$ absorption $(P<0.001)$. Severely or mildly anaemic rats, when fed on the $\mathrm{FeSO}_{4} \cdot 7 \mathrm{H}_{2} \mathrm{O}$ diet, excreted less $\mathrm{Fe}$ in the faeces and had a higher apparent absorption than those fed on diets with food Fe sources (Table 5). However, in non-anaemic rats, faecal Fe loss and apparent absorption were similar for the rats fed on the $\mathrm{FeSO}_{4} \cdot 7 \mathrm{H}_{2} \mathrm{O}$ diet and food $\mathrm{Fe}$ diets. In rats fed on the $\mathrm{FeSO}_{4} \cdot 7 \mathrm{H}_{2} \mathrm{O}$ diet, the initial haemoglobin level was positively related to faecal Fe excretion, and negatively related to apparent absorption (Table 4). However, these relations were not apparent in rats fed on diets with $\mathrm{Fe}$ from meat or spinach. Of the nonanaemic rats, those fed on spinach had the lowest apparent $\mathrm{Fe}$ absorption. However, all the $\mathrm{Fe}$-deficient rats absorbed more Fe from spinach than from the other sources of food $\mathrm{Fe}$. The pattern of HRE (Table 3) for all these animals was similar to that of apparent $\mathrm{Fe}$ absorption ( $r$ 0.87). Both methods are affected by Fe status and both distinguish differences in the bioavailability of Fe. 


\section{Relative $H R E$ and relative $F e$ absorption}

The relative HRE and relative Fe absorption of rats fed on meat, spinach or meat-spinach mixtures are shown in Table 6. The HRE of anaemic rats fed on meat or meat-spinach mixtures was about $60 \%$ of that of rats fed on the $\mathrm{FeSO}_{4} \cdot 7 \mathrm{H}_{2} \mathrm{O}$ diet. This finding is similar to that observed for meat by Jansuittivechakul et al. $(1985,1986)$ and Shah et al. (1983). On meat, meat-spinach and spinach diets, the mildly anaemic and non-anaemic rats had higher relative HREs than the severely anaemic rats. This is because the HRE for rats on the $\mathrm{FeSO}_{4} \cdot 7 \mathrm{H}_{2} \mathrm{O}$ diet was inversely associated $(r-0.79)$ with initial haemoglobin concentration (Table 4), but there was little or no association between initial haemoglobin concentration and HRE for rats on the meat, meat-spinach or spinach diets. Therefore, relative HRE of mildly anaemic and non-anaemic rats fed on the meat diet increased to 77 and $98 \%$ respectively. The relative HRE values of the mildly anaemic and non-anaemic rats fed on the spinach diet increased to 80 and $75 \%$, respectively. The pattern of relative Fe absorption among severely and mildly anaemic and non-anaemic rats was similar to that of relative HRE values.

\section{DISCUSSION}

\section{The effect of Fe status on Fe bioavailability}

On the $\mathrm{FeSO}_{4} \cdot 7 \mathrm{H}_{2} \mathrm{O}$ diet, rats with the lowest initial haemoglobin had the highest HRE and apparent $\mathrm{Fe}$ absorption; on the spinach diet, they were highest in the mildly anaemic rats; and on the meat diet, they were unaffected by haemoglobin level. It is possible that the ability of the severely Fe-deficient rats to absorb haem-Fe (beef) or non-haem-Fe complex (spinach) in foods may have been damaged somehow without affecting the ability to absorb simple inorganic $\mathrm{Fe}\left(\mathrm{FeSO}_{4} \cdot 7 \mathrm{H}_{2} \mathrm{O}\right)$. It is also possible that both the anaemic and non-anaemic rats utilized all the metabolizable $\mathrm{Fe}$ available in diets containing food $\mathrm{Fe}$, and that the metabolizable $\mathrm{Fe}$ available in the $\mathrm{FeSO}_{4} \cdot 7 \mathrm{H}_{2} \mathrm{O}$ diet exceeded the requirements of the non-anaemic rats, which then absorbed (Table 5) and utilized (Table 3) less Fe than Fe-deficient rats. But this cannot explain why mildly anaemic rats had higher HRE and apparent $\mathrm{Fe}$ absorption than severely anaemic rats fed on the spinach diet; rather, this may be due to random experimental variations between trials 1 and 2 .

\section{Utilization of Fe from spinach and beef}

The results of the present study were similar to those of Pye \& MacLeod (1946), who found that anaemic rats retained $26 \%$ of the Fe from spinach and $32 \%$ from beef muscle. The absorption of spinach $\mathrm{Fe}$ relative to meat $\mathrm{Fe}$ in the present study was similar to that in a study involving human subjects by MacMillan \& Johnston (1951). They found that subjects on a spinach diet absorbed $11.4 \%$ of the dietary $\mathrm{Fe}$, and subjects on a spinach-beef diet absorbed $9.5 \%$ of the dietary $\mathrm{Fe}$; the difference was not statistically significant. The differences in percentage $\mathrm{Fe}$ absorption between the animal and human studies are probably due to differences in $\mathrm{Fe}$ status, maturity and $\mathrm{Fe}$ intake relative to requirement (Thannoun et al. 1988). The high quantity and utilization of $\mathrm{Fe}$ in spinach (Pye \& MacLeod, 1946; Ruegamer et al. 1946; McMillan \& Johnston, 1951; Van Campen \& Welch, 1980) means that spinach should be a good Fe source.

\section{Effect of meat on Fe absorption}

Meat is a high-quality Fe source (Cardon et al. 1980; Jansuittivechakul et al. 1985, 1986; Thannoun et al. 1987) that enhances the absorption of non-haem-Fe from other components of a meal (Layrisse et al. 1968, 1984; Cook \& Monsen, 1976). Most of the 


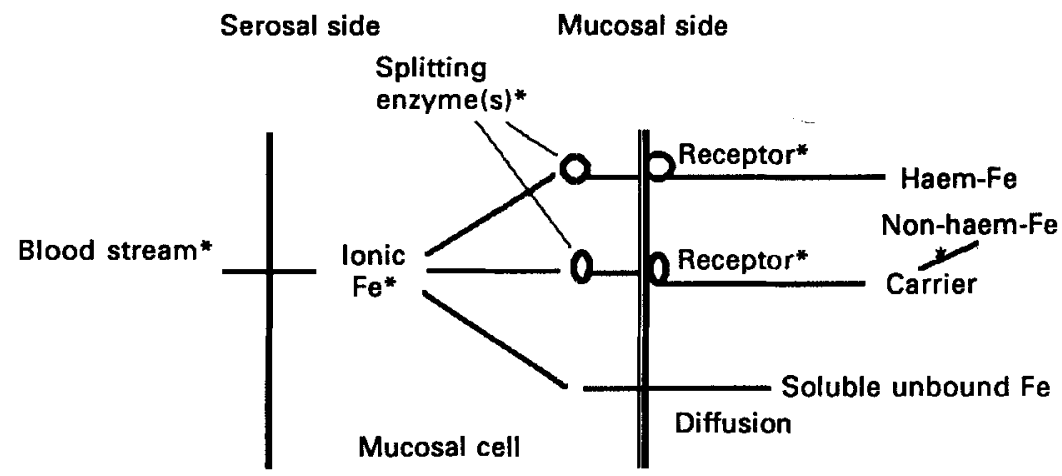

Fig. 1. Suggested mechanism of iron absorption (three Fe pool hypothesis). * Control points for Fe absorption.

experiments showing this enhancement involved measuring absorption of extrinsic radio$\mathrm{Fe}$ labels. This method measures only the absorption of non-haem-Fe, not the total $\mathrm{Fe}$ in food, and involves one acute dose over a very short period of time. This technique would not indicate whether the absorption of haem-Fe in meat was reduced when the absorption of non-haem-Fe was enhanced. Martínez-Torres \& Layrisse (1971) used a dual radioisotope technique and found that non-haem-Fe absorption from maize (Zea mays) and black bean (Phaseolus nigra) increased by 87 and $121 \%$ respectively when meat was added to the meal. However, the absorption of Fe from meat was reduced. Total dietary $\mathrm{Fe}$ absorption was slightly lower when the meal contained maize and meat or black beans and meat.

Similar to our findings with rats, McMillan \& Johnston (1951) concluded that meat did not affect absorption of spinach Fe by young women. They found that Fe absorption increased in the first week when meat was given with spinach, but then decreased to a level lower than that from the spinach diet during the following 3 weeks. Thus, short-term experiments, especially those involving a single dose, may not accurately reflect actual $\mathrm{Fe}$ absorption.

\section{Hypothesis of a third Fe pool}

In our experiment, the pattern of $\mathrm{Fe}$ absorption from the different $\mathrm{Fe}$ sources indicates that the commonly accepted non-haem-Fe pool may be separated into two: a simple inorganic non-haem-Fe salt pool and an organically complexed non-haem-Fe pool (Fig. 1). Gitlin \& Cruchaud (1962) suggested that two different mechanisms of Fe absorption might operate simultaneously in the gastrointestinal lumen: (1) a process in which absorption is limited by the amount of carrier, and (2) a first-order process governed by the amount of absorbable $\mathrm{Fe}$ in the gastrointestinal lumen. They also suggested that diffusion, a first-order process, may be one of the mechanisms of control. Geisser \& Müller (1987) reported that ferrous sulphate and ferric-hydroxide polymaltose (ferripolymaltose) appear to be governed by totally different Fe absorption or distribution mechanisms, or both; the absorption of ferrous sulphate may depend on passive diffusion, which is only limited by the membrane surface area and the Fe concentration gradient, while the absorption of ferripolymaltose may depend on active transport, which is energy dependent.

Non-haem-Fe complexes (such as $\mathrm{Fe}$ in spinach or ferripolymaltose) need to be bound to a carrier protein which may limit Fe absorption either by differences in binding of the carrier with the Fe complex, or by differences in movement of the Fe-complex-loaded carrier across the mucosal cell membrane. Haem-Fe is absorbed intact by the mucosal cells 
via a carrier system. In severe Fe deficiency, the function of the carrier system may be reduced by pathological factors, such as reduced Fe enzyme activity, reduced energy supply or low $\mathrm{O}_{2}$ supply. Thus, the absorption of both non-haem- and haem-Fe complexes may be affected by the carrier system that allows $\mathrm{Fe}$ to pass through the membrane into mucosal cells. However, highly soluble, simple inorganic Fe salts (such as $\mathrm{FeSO}_{4} \cdot 7 \mathrm{H}_{2} \mathrm{O}$ ) diffuse into mucosal cells and are not affected by the carrier system. Once in the mucosal cells, all three $\mathrm{Fe}$ pools seem to enter the bloodstream via the same pathway, which is regulated by $\mathrm{Fe}$ requirements. $\mathrm{Fe}$ in excess of the body requirement is trapped as ferritin and discarded when the mucosal cells exfoliate. The portion of Fe needed by the body is bound to transferrin, which is released into the blood.

\section{Relative Fe bioavailability ( $R I B A)$}

RIBA is the Fe bioavailability of a test source expressed as a percentage of the $\mathrm{Fe}$ bioavailability of a reference material, usually ferrous sulphate $(100 \%)$. This makes it possible to control for extraneous dietary and environmental factors that may affect $\mathrm{Fe}$ bioavailability and to rate $\mathrm{Fe}$ sources. This approach assumes that factors affecting the absorption of $\mathrm{Fe}$ in food will also have the same effect on the absorption of reference $\mathrm{Fe}$. However, this may not always be true. In our experiments, severe Fe depletion increased the amount of $\mathrm{Fe}$ that rats absorbed from a diet containing $\mathrm{FeSO}_{4} \cdot 7 \mathrm{H}_{2} \mathrm{O}$, but did not increase absorption of $\mathrm{Fe}$ from food sources (Table 5). The higher RIBA in the nonanaemic rats was due to a decreased absorption of $\mathrm{Fe}$ from $\mathrm{FeSO}_{4} \cdot 7 \mathrm{H}_{2} \mathrm{O}$, not an increased absorption of $\mathrm{Fe}$ from foods. The $\mathrm{HRE}$ of non-anaemic rats was similar regardless of whether diets contained $\mathrm{Fe}$ from $\mathrm{FeSO}_{4} \cdot 7 \mathrm{H}_{2} \mathrm{O}$ or from foods. However, the HRE of anaemic rats was much higher when diets contained $\mathrm{FeSO}_{4} \cdot 7 \mathrm{H}_{2} \mathrm{O}$. If, as we hypothesize, $\mathrm{FeSO}_{4} \cdot 7 \mathrm{H}_{2} \mathrm{O}-\mathrm{Fe}$ is not in the same gastrointestinal pool as non-haem-Fe complex, calculation of RIBA would give confusing results. Thus, an Fe complex may be a better reference material for determining RIBA of foods than $\mathrm{FeSO}_{4} \cdot 7 \mathrm{H}_{2} \mathrm{O}$.

This research was supported by the National Live Stock \& Meat Board and Experiment Station project no. 253. The authors thank Dr Ron Canfield, Department of Mathematics, for assistance with the statistical analyses.

\section{REFEREN CES}

Agricultural Research Service, United States Department of Agriculture (1963). Composition of Foods. Agriculture Handbook no. 8. Washington DC: US Government Printing Office.

Association of Official Analytical Chemists (1980). Official Methods of Analysis, 13th ed. Washington DC: Association of Official Analytical Chemists.

Atherton, H. V. \& Newlander, J. A. (1982). Chemistry and Testing of Dairy Products, 4th ed., pp. $105-116$. Westport, Connecticut: AVI Publishing Company Inc.

Beutler, E. (1980). Iron. In Modern Nutrition in Health and Disease, 6th ed., p. 136 [R. S. Goodhart and M. E. Shils, editors]. Philadelphia: Lea \& Febiger.

Björn-Rasmussen, E. \& Hallberg, L. (1979). Effect of animal proteins on the absorption of food iron in man. Annals of Nutrition and Metabolism 23, 192-202.

Björn-Rasmussen, E., Hallberg, L. \& Walker, R. B. (1973). Food iron absorption in man II: isotopic exchange of iron between labelled foods and between a food and an iron salt. American Journal of Clinical Nutrition 26, 1311-1319.

Cardon, K. M., Anthony, R. J., Hendricks, D. G. \& Mahoney, A. W. (1980). Effect of atmospheric oxidation on bioavailability of meat iron and liver weights in rats. Journal of Nutrition 110, 567-574.

Carma, S. G. \& Swanson, M. R. (1973). An evaluation of ten pairwise multiple comparison procedures by Monte Carlo methods. Journal of the American Statistical Association 68, 66-74.

Cook, J. D. \& Monsen, E. R. (1976). Food iron absorption in human subjects. III. Comparison of the effect of animal proteins on nonheme iron absorption. American Journal of Clinical Nutrition 29, 859 867.

Dowdy, S. \& Wearden, S. (1983). Statistics for Research. New York: John Wiley \& Sons, Inc. 
Fiske, C. H. \& Subbarow, Y. (1925). The colorimetric determination of phosphorus. Journal of Biological Chemistry 66, 375 400 .

Geisser, P.\& Müller, A. (1987). Pharmacokinetics of iron salts and ferric hydroxide carbohydrate complexes. Arzneim.-Forsch./Drug Research 37, 100-104.

Gillooly, M., Torrance, J. D., Bothwell, T. H., Macphail, A. P., Derman, D., Mills, W. \& Mayet, F. (1984). The relative effect of ascorbic acid on iron absorption from soy-based and milk-based infant formulas. American Journal of Clinical Nutrition 40, 522-527.

Gitlin, D. \& Cruchaud, A. (1962). On the kinetics of iron absorption in mice. Journal of Clinical Investigation 41, $344-350$.

Jansuittivechakul, O., Mahoney, A. W., Cornforth, D. P., Hendricks, D. G. \& Kangsadalampai, K. (1985). Effect of heat treatment on bioavailability of meat and hemoglobin iron fed to anemic rats. Journal of Food Science 50, $407-409$.

Jansuittivechakul, O., Mahoney, A. W., Cornforth, D. P., Hendricks, D. G. \& Sisson, D. V. (1986). Effect of heat treatment on meat enhancement of dietary iron bioavailability of meat/ferrous sulfate and meat/hemoglobin mixtures fed to anemic rats. Journal of Food Science 51, 263-267.

Latunde-Dada, G. O. \& Neale, R. J. (1986). Effect of soya-bean protein on meat iron solubility and absorption in rats. British Journal of Nutrition 55, 419-426.

Layrisse, M., Cook, J. D., Martínez-Torres, C., Roche, M., Kuhn, I. N., Walker, R. B. \& Finch, C. A. (1969). Food iron absorption: a comparison of vegetable and animal foods. Blood 33, 430 443 .

Layrisse, M., Martínez-Torres, C., Leets, I., Taylor, P. \& Ramírez, J. (1984). Effect of histidine, cysteine, glutathione or beef on iron absorption in humans. Journal of Nutrition 114, 217-223.

Layrisse, M., Martínez-Torres, C. \& Roche, M. (1968). Effects of interaction of various foods on iron absorption. American Journal of Clinical Nutrition 21, 1175-1183.

McMillan, T. J. \& Johnston, F. A. (1951). The absorption of iron from spinach by six young women, and the effect of beef upon the absorption. Journal of Nutrition 44, 383-398.

Mahoney, A. W. \& Hendricks, D. G. (1976). Effect of dietary iron level on efficiency of converting food iron into hemoglobin by the anemic rat. Nutrition Metabolism 20, 222-227.

Mahoney, A. W. \& Hendricks, D. G. (1982). Efficiency of hemoglobin regeneration as a method of assessing iron bioavailability in food products. In Nutritional Bioavailability of Iron, pp. 1-11 [C. Kries, editor]. Washington DC: American Chemical Society

Mahoney, A. W., Van Orden, C. C. \& Hendricks, D. G. (1974). Efficiency of converting food iron into hemoglobin by the anemic rat. Nutrition Metabolism 17, 223-230.

Martínez-Torres, C. \& Layrisse, M. (1971). Iron absorption from veal muscle. American Journal of Clinical Nutrition 24, 531-540.

Miller, J. (1982). Factors affecting evaluation of relative biological value of dietary iron for rats. Journal of Nutrition 12, 2381-2385.

Pye, O. F. \& MacLeod, G. (1946). The utilization of iron from different foods by normal young rats. Journal of Nutrition 32, 677-687.

Ruegamer, W. R., Michaud, L., Hart, E. B. \& Elvehjem, C. A. (1946). The use of the dog for studies on iron availability. Journal of Nutrition 32, 101-111.

Shah, B. G., Giroux, A. \& Belonje, B. (1983). Bioavailability of iron in ground beef and plant protein concentrates. Nutrition Research 3, 547-555.

Thannoun, A. M., Mahoney, A. W., Hendricks, D. G. \& Zhang, D. (1987). Effect of meat-bread mixtures on bioavailability of dietary iron for anemic rats. Cereal Chemistry 64, 399-403.

Thannoun, A. M., Mahoney, A. W., Sisson, D. V. \& Hendricks, D. G. (1988). Heme and nonheme iron absorption from meat and meat loaf by anemic and healthy rats. Nutrition Reports International 37 , 487-497.

Timm, K. (1979). Orbital venous anatomy of the rat. Laboratory Animal Science 29, 636-638.

Turnbull, A. (1974). Iron absorption. In Iron in Biochemistry and Medicine, pp. $369-403$ [A. Jacobs and M. Worwood, editors]. Orlando, FL: Academic Press.

Van Campen, D. \& Welch, R. M. (1980). Availability to rats of iron from spinach: effects of oxalic acid. Journal of Nutrition 110, 1618-1621.

Weintraub, L. R., Weinstein, M. B., Huser, H. \& Rafal, S. (1968). Absorption of hemoglobin iron: the role of a heme-splitting substance in the intestinal mucosa. Journal of Clinical Investigation 47, 531-539.

Wollenberg, P. \& Rummel, W. (1987). Dependence of intestinal iron absorption on the valency state of iron. Naunyn-Schmiedeberg's Archives of Pharmacology 336, 578-582. 